\section{Studia z Filologii Polskiej i Słowiańskiej}

DOI: $10.11649 /$ sfps.1973
Studia z Filologii Polskiej i Słowiańskiej, 55

Warszawa 2020

Article No. 1973

Citation:

Stec, W. (2020). Interferencja w przekładzie jako skutek wzajemnych oddziaływań języków (na przykładzie tłumaczeń tekstów z zakresu prawa w parze językowej polski-rosyjski). Studia z Filologii Polskiej i Stowiańskiej, 55, Article 1973. https:// doi.org/10.11649/sfps.1973

Wanda Stec

(Uniwersytet Gdański)

\title{
Interferencja w przekładzie jako skutek wzajemnych oddziaływań języków (na przykładzie tłumaczeń tekstów z zakresu prawa w parze językowej polski-rosyjski)
}

Interferencja zazwyczaj rozpatrywana jest w kontekście nauki języków obcych, w sytuacji pogranicza językowego czy w warunkach migracji. Problematyce interferencji w ujęciu glottodydaktycznym - jej przyczynom, postaciom i konsekwencjom - poświęcono wiele interesujących publikacji naukowych (Bawej, 2008; Grucza, 1978; Walczak, 2014). W niniejszym artykule zostaną poruszone wybrane zagadnienia transferu językowego, jaki ma miejsce w procesie przekładu, w oparciu o analizę tłumaczeń tekstów z zakresu prawa (prawnych i prawniczych). Na potwierdzenie wysuniętych tez będą przedstawione błędy, obecne zarówno w sytuacji tłumaczenia na język obcy, jak i na ojczysty, które, zdaniem autorki, wynikają z interferencji polskiego bądź rosyjskiego systemu językowego, będącej skutkiem wzajemnego oddziaływania języków w przekładzie.

This is an Open Access article distributed under the terms of the Creative Commons Attribution 3.0 PL License (creativecommons.org/licenses/by/3.0/pl/), which permits redistribution, commercial and non-commercial, provided that the article is properly cited. (c) The Author(s) 2020.

Publisher: Institute of Slavic Studies, Polish Academy of Sciences

[Wydawca: Instytut Slawistyki Polskiej Akademii Nauk] 
Materiał badawczy stanowią pisemne przekłady tekstów wykonane przez studentów filologii rosyjskiej Uniwersytetu Gdańskiego w ramach prowadzonych przez autorkę zajęć dydaktycznych. Były to przedmioty realizowane w formie ćwiczeń, takie jak: Przekład tekstów specjalistycznych (teksty prawne i prawnicze), Analiza językowa i przekład tekstów prawnych, Organizacja i technika pracy tłumacza przysięgłego, Przekład prawniczy (warsztaty). Teksty z zakresu prawa, które tłumaczono, to m.in. wezwania sądowe, orzeczenia (postanowienia, wyroki), pouczenia o uprawnieniach i obowiązkach (podejrzanego, pokrzywdzonego), fragmenty aktów prawnych, komentarze do przepisów prawa, umowy, pełnomocnictwa, zaświadczenia, pisma urzędowe, korespondencja dyplomatyczna. Językiem wyjściowym przekładu był rosyjski albo polski.

Powstawaniu zjawisk interferencyjnych w sposób bezpośredni sprzyjają kontakty językowe, rozumiane jako oddziaływanie na siebie dwóch lub więcej języków, prowadzące do zmian strukturalnych i słownikowych w jednym lub wielu z nich (Sękowska, 2010, ss. 34-35). W wyniku takiego oddziaływania może zachodzić „nakładanie się systemów i wzajemne przenikanie należących do nich elementów" (Bugajski, 2006, s. 319). Marian Bugajski słusznie zauważa, że kontakty międzyjęzykowe „są następstwem wszelkiego rodzaju innych kontaktów: kulturalnych, handlowych, politycznych. W każdej z tego rodzaju działalności na styku różnych nacji zachodzi konieczność tłumaczenia tekstów. I właśnie w tym należałoby się dopatrywać najpoważniejszego źródła interferencji” (Bugajski, 2006, s. 324).

Powstający w wyniku kontaktu międzyjęzykowego przekład (Lewicki, 2000, s. 62) umożliwia ludziom skuteczne komunikowanie się, zatem jego fundamentem jest sprawne posługiwanie się dwoma językami etnicznymi, czyli bilingwizm, z którym ściśle wiąże się zjawisko interferencji (Dzierżanowska, 1990, s. 28). U studentów neofilologii najczęściej mamy do czynienia z bilingwizmem wyuczonym, asymetrycznym i podporządkowanym, gdyż język drugi nabywany jest poprzez język pierwszy (por. Cieszyńska, 2006, ss. 40-43). Przełączanie kodów językowych jest zatem w tej sytuacji przynajmniej częściowo kontrolowane i uwarunkowane potrzebą tłumaczenia. Przyswajanie nowego języka odbywa się „poprzez filtr uprzednio opanowanego (przyswojonego) materiału językowego" (Grucza, 1981, ss. 16-17) za pomocą transferu nabytej wiedzy, nawyków, przyzwyczajeń itp. na pokrewne lub analogiczne działania, przy czym „tam, gdzie zachodzi odmienność strukturalna, może wystąpić zjawisko tzw. transferu negatywnego, które w lingwistyce i glottodydaktyce nazywa się zwykle interferencją. Interferencja jest więc zjawiskiem niepożąda- 
nym, prowadzi bowiem do tworzenia błędnych struktur i błędnych realizacji" (Grucza, 1981, s. 17; por. Szulc, 1984, s. 94).

Nauczanie przekładu pokazuje, że interferencja stanowi poważny problem dla początkujących tłumaczy, uzewnętrzniając się na wszystkich poziomach języka (Alimov, 2006, ss. 17-20). Proces tłumaczenia to praktyczna realizacja użycia dwóch języków etnicznych, toteż tłumacze z założenia narażeni są na działanie interferencji - przede wszystkim zewnętrznej (interlingwalnej). Dlatego też przekład - jak udowadnia Halina Dzierżanowska - „jest ciągłym zmaganiem się z interferencją" (Dzierżanowska, 1990, s. 43). Urszula Dąmbska-Prokop podkreśla, że transfer „jest w mniejszym czy większym stopniu zjawiskiem nieodłącznym od tłumaczenia" (Dąmbska-Prokop, 2000, s. 264), przy czym zależy on od kompetencji językowej tłumacza, zazwyczaj niejednakowej w dwóch językach, jak również od jego doświadczenia i „warunków, w jakich przebiega tłumaczenie". W sytuacji przekładu z języka ojczystego na obcy powstaje naturalny impuls do zachowania struktur rodzimych, dlatego bardzo ważne jest opanowanie przez tłumacza języka przekładu w takim stopniu, aby eliminować interferencję języka, z którego się tłumaczy (Dzierżanowska, 1990, s. 29).

Interferencja występuje w tłumaczeniach wykonywanych w dowolnej formie: ustnych, pisemnych, a także $\mathrm{w}$ formach pośrednich. $\mathrm{Z}$ badań prowadzonych w tym zakresie nad tłumaczeniem a vista wynika, że 75\% popełnianych błędów stanowią właśnie błędy interferencyjne (Płużyczka, 2015, ss. 71, 131). Zofia Kozłowska i Anna Szczęsny (Kozłowska \& Szczęsny, 2018, s. 236) stoją na stanowisku, że interferencja jest najczęstszą przyczyną błędów językowych w przekładzie. Urszula Dąmbska-Prokop, odnosząc się do kulturowych uwarunkowań transferu językowego w tłumaczeniu, odwołuje się do sformułowanego przez Gideona Toury’ego (Toury, 1995, s. 275) tzw. "prawa interferencji”, zgodnie z którym tłumacz stara się przenieść do tekstu docelowego zjawiska, które uznaje za ważne w języku wyjściowym. Autorka zwraca przy tym uwagę, że zasada ta „dotyczy zarówno tłumaczenia z języka ojczystego na obcy, jak i sytuacji odwrotnej, chociaż na ogół pojęcie transferu i interferencji wiąże się głównie z kompetencją językową i kulturową w języku ojczystym" (Dąmbska-Prokop, 2000, s. 265).

Kompetencja językowa nie jest kluczowa w tłumaczeniu na język ojczysty, co zauważa Zofia Kozłowska, analizując błędy w tłumaczeniach z rosyjskiego na polski. Z jej badań wynika, że główną ich przyczyną „nie jest nieznajomość języka przekładu, który jest przecież językiem ojczystym, lecz interferencja” 
(Kozłowska, 2002, s. 140). Autorka stwierdza, że są to raczej błędy performancji (wykonania), związane z tym, że początkujący tłumacz nie jest w stanie zapobiec wpływowi języka oryginału (Kozłowska, 2002, s. 138). Małgorzata Guławska-Gawkowska także utrzymuje, że „drugim i najczęstszym źródłem błędów w tłumaczeniu na język polski jest interferencja $\mathrm{z}$ języka wyjściowego na język docelowy tłumaczenia, który jest w tym wypadku językiem ojczystym” (Guławska-Gawkowska, 2005, s. 70) ${ }^{1}$.

Bogumił Gasek zauważa, że w początkowym stadium nauki języka obcego zjawisko interferencji leksykalno-semantycznej ma charakter wyłącznie jednostronny, polegający na tym, że język ojczysty wywiera wpływ na przyswajany język obcy. Jednakże w sytuacji kształcenia neofilologicznego na poziomie uniwersyteckim zachodzi także interferencja tłumaczeniowa w kierunku przeciwnym, tj. oddziaływanie języka będącego przedmiotem uczenia się na język rodzimy studenta (Gasek, 2012, s. 32).

W przekładzie wskutek interferencji powstają przede wszystkim błędy językowe obecne na różnych płaszczyznach języka - fonetycznej, morfologicznej, składniowej, leksykalnej, semantycznej. Pod wpływem interferencji może dojść również do pojawienia się błędów tłumaczeniowych prowadzących do zakłócenia relacji ekwiwalencji między tekstem źródłowym a tekstem docelowym poprzez nieprzekazanie treści oryginału. Tego typu błędy wynikają z nieuwzględnienia semantyki tekstu wyjściowego oraz pominięcia w tłumaczeniu warstwy stylistycznej oryginału lub jego uwarunkowań pragmatycznych (Guławska-Gawkowska, 2005, s. 70). Zofia Kozłowska i Anna Szczęsny (Kozłowska \& Szczęsny, 2018, s. 236) zwracają uwagę, że błędy leksykalne, czyli niewłaściwie dobrane odpowiedniki wyrazowe, powodują wypaczenie sensu i z tego powodu są jednocześnie błędami tłumaczeniowymi. Roman Lewicki uważa, że błędy w przekładzie „można podzielić na dwa typy: a) błędy językowe (przeciwko normie $\mathrm{JP}^{2}$ oraz jego charakterystykom uzualnym), b) błędy przekładowe (przeciwko ekwiwalencji wobec oryginału)" (Lewicki, 2000, s. 138).

Interferencja w tłumaczeniu stanowi zatem najczęściej „naruszenie normy języka docelowego pod wpływem języka wyjściowego" (Lukszyn, 1998,

1 Jako pierwsze źródło Guławska-Gawkowska podaje „brak wiedzy dotyczącej norm fleksyjnych współczesnej polszczyzny”, wynikający z niedostatecznego kształcenia polonistycznego absolwentów szkół średnich (Guławska-Gawkowska, 2005, s. 70).

${ }^{2}$ JP - język przekładu. 
s. 123). Jest to zjawisko niepożądane, prowadzące do niewiernego przekazu i zakłócenia komunikacji międzyjęzykowej, dlatego też winno być w odpowiednim czasie wykryte, wyjaśnione i skorygowane. Umiejętność „wykrywania interferencji i przeciwdziałania jej” Dzierżanowska uznaje za jedno z najważniejszych kryteriów znajomości języka obcego, które pozwala na dokonywanie tłumaczeń na ten język (Dzierżanowska, 1990, s. 27). Zasady poprawności językowej są, zdaniem Danuty Kierzkowskiej, ważne w tłumaczeniu zarówno na poziomie poszczególnych elementów tekstu, jak i całego tekstu (Kierzkowska, 2002, s. 82). Wnikliwa analiza dokonanych przekładów, a następnie wyjawienie popełnionych błędów umożliwiają ustalenie strategicznych punktów wynikających z różnic między językiem źródłowym i docelowym oraz pozwalają na zapobieżenie potencjalnemu wystąpieniu transferu negatywnego. Studenci uczą się na własnych błędach, poznając ich charakter oraz mechanizmy powstawania. Dzięki temu lepiej opanowują język obcy i - w przypadku, jeśli analizują tłumaczenie $\mathrm{z}$ rosyjskiego na polski - doskonalą język ojczysty.

Tłumaczom w parze językowej polski-rosyjski nie ułatwia pracy podobieństwo tych języków (czasem złudne), które wręcz sprzyja transferowi. Izabela Bawej pisze o przesłance glottodydaktycznej mówiącej, że „transfer następuje najczęściej, gdy języki są do siebie genetycznie zbliżone" (Bawej, 2008, s. 73). Praktyka pokazuje, że transfer negatywny obecny jest na wszystkich poziomach języka, przyczyniając się do braku poprawności językowej translatów, a także do modyfikacji czy zmiany sensu w przetłumaczonym tekście. Początkującym adeptom przekładu trudno jest uniknąć interferencji zewnętrznej, mimo że mają oni podstawową wiedzę o występowaniu takiego zjawiska $\mathrm{i}$ - jak się wydaje - zdają sobie sprawę z wynikających zeń niebezpieczeństw dla komunikacji międzyjęzykowej. Niemniej jednak szukając odpowiednika dla jednostki tłumaczenia, bezrefleksyjnie przenoszą do języka docelowego struktury z języka wyjściowego.

Odbiór tekstów z zakresu prawa ma charakter kontekstowy i odbywa się na dwóch poziomach - deskryptywnym (językowym) oraz dyrektywnym (recepcja norm prawnych) (Nawacki \& Nawacka, 2007, ss. 146-147). Teksty owe odznaczają się swoistymi cechami występującymi na różnych poziomach struktury języka, takimi jak: dyrektywność wypowiedzi, bezosobowość, precyzyjność, zrozumiałość, logika wywodu, rzeczowość, standaryzacja, specyficzne słownictwo i reguły semantyczne (Choduń, 2007, ss. 35-36). $\mathrm{W}$ świetle powyższego w ich tłumaczeniu wymagana jest dokładność i bez- 
warunkowe przestrzeganie ścisłości terminologiczno-znaczeniowej, szczególnie istotne w przekładzie poświadczonym, gdzie konsekwencje prawne niedokładnego lub błędnego tłumaczenia mogą być poważne zarówno dla odbiorcy przekładu, jak i dla tłumacza. Zgodnie z zapisami ustawowymi tłumacz przysięgły jest zobowiązany do wykonywania powierzonych mu zadań ze szczególną starannością, która nakazuje, aby „przekazana $\mathrm{w}$ translacie treść była zgodna $\mathrm{z}$ treścią oryginału, a także cechowała się poprawnością leksykalną, gramatyczną i ortograficzną oraz właściwym stylem funkcjonalnym" (Kubacki, 2014, s. 54). Teksty prawne i prawnicze, z jakimi najczęściej ma do czynienia tłumacz przysięgły, charakteryzują się wysoką frekwencją słownictwa specjalistycznego, dlatego trudności sprawia nie tylko ich przekład, ale czasem nawet zrozumienie i właściwa interpretacja w języku wyjściowym.

W celu zobrazowania zjawiska interferencji w tłumaczeniu tekstów z zakresu prawa przedstawiony zostanie materiał faktograficzny opisany na wstępie artykułu. W przykładach formy błędne poprzedzone są gwiazdką *, formy właściwe podano w nawiasie (). Przy wyszczególnianiu błędów wykorzystano klasyfikacje i charakterystyki zamieszczone w pracach Andrzeja Markowskiego (Markowski, 2005), Haliny Dzierżanowskiej (Dzierżanowska, 1990), Franciszka Gruczy (Grucza, 1978) i Zofii Kozłowskiej (Kozłowska, 2002). Część błędów w tekstach tłumaczeń dotyczy jednak kilku płaszczyzn języka równocześnie, ma różne przyczyny oraz implikacje dla przekładu, dlatego też wymykają się one próbom jednoznacznej kwalifikacji. Stąd też pogrupowano je w sposób odzwierciedlający oddziaływanie interferencji na proces i rezultat tłumaczenia.

Stosunkowo dużo błędów interferencyjnych dotyczy leksyki i frazeologii. Wydaje się to logiczne, ponieważ słownictwo jest tą warstwą języka, która najszybciej ulega zmianom w warunkach kontaktu językowego (Sękowska, 2010, s. 69). Analiza prac tłumaczeniowych pokazuje, że czasem studenci, licząc na łut szczęścia, poniekąd z rozmysłem tworzą kalki i zapożyczenia, jakie w rzeczywistości nie istnieją w języku docelowym. Nie jest to jednak świadome rozwiązanie translatorskie, a więc takie, którego celem byłoby zwrócenie uwagi odbiorcy przekładu na obce pochodzenie tłumaczonego tekstu oraz kultury, w jakiej ów tekst powstał. W przypadku tłumaczenia na język obcy może ono wynikać z niedostatecznej znajomości języka, w tym z ograniczonego zasobu słownictwa i zasobu frazeologicznego. Wskutek interferencji w przekładzie 
Wanda Stec Interferencja w przekładzie jako skutek wzajemnych oddziaływań języków...

powstają błędne elementy i struktury językowe, a zatem są to nieświadome odstępstwa od normy językowej, które mogą skutkować nieoddaniem treści tłumaczonego tekstu. W wyniku naśladowania obcojęzycznych wzorów w tłumaczeniu na język ojczysty tworzone są kalki językowe, jak wyrazy i konstrukcje typu:

базироваться - *bazować (opierać się na czymś);

ведущий - ${ }^{*}$ wiodący (główny, najważniejszy);

oбecneчumb - *zabezpieczyć (zapewnić, zagwarantować);

тем не менее - ${ }^{\star}$ tym niemniej (niemniej, niemniej jednak).

W tłumaczeniach studentów pojawiają się wyrazy i konstrukcje nieistniejące w języku docelowym, np. polskie wyrazy pisane cyrylicą, błędne konstrukcje (błędy w zakresie łączliwości leksykalnej), ma miejsce przenoszenie $\mathrm{z}$ języka wyjściowego do języka docelowego nieistniejących w nim skrótów:

odpis dokumentu - *одпись, ${ }^{\star}$ одпис документа (копия документа);

$z d n i a-{ }^{*} \mathrm{c} \partial н я,{ }^{*}$ co дня (om + data, bez użycia wyrazu $\left.d z i e n ́\right) ;$

pod nuтегет - ${ }^{\star}$ под номером (за номером);

$w$ terminie $-{ }^{*}$ в сроке (в срок), ${ }^{\star} в$ термине

- tu również użycie wyrazu w nietrafnym znaczeniu;

np. - ${ }^{*}$ Hn. (Hanp.).

Błędy leksykalne wynikające z tendencji do kalkowania mogą zmienić sens wypowiedzi, a zatem są to też błędy tłu maczeniowe:

w sprawie - ${ }^{*}$ в деле (по делу);

sq̨dоwy - ${ }^{*}$ судовы $\breve{\text {, }}{ }^{*}$ судовой ${ }^{3}$ (судебныц $)$;

гербовая печать - pieczęć * $z$ herbem, pieczęć *herbowa (pieczęć urzędowa, pieczęć zawierająca godło);

зарегистрироваться по адресу - *zarejestrować się pod adresem (zameldować się);

дорожные чеки - czeki ${ }^{*}$ drogowe (czeki podróżne).

Dość często studenci popełniają błędy słownikowe spowodowane niewłaściwym doborem odpowiednika przekładowego w przypadku wyrazów

${ }^{3}$ Czyli 'okrętowy'. 
Wanda Stec Interferencja w przekładzie jako skutek wzajemnych oddziaływań języków...

wieloznacznych, skutkującym użyciem wyrazu w niewłaściwym znaczeniu, także w składzie kolokacji:

wyłączenie sędziego, czyli odsunięcie go od orzekania w sprawie - ${ }^{*}$ исключение, ${ }^{\star}$ выключение судьи (отвод судьи);

муниципальное образование - ${ }^{*}$ wykształcenie, ${ }^{*}$ edukacja ${ }^{*}$ municypalna

(jednostka samorządu terytorialnego);

minister sprawiedliwości-министр ${ }^{*}$ справедливости (юстиции);

wniosek - ${ }^{\star}$ выьвод, ${ }^{*}$ заявка, ${ }^{*}$ заявление (ходатайство);

złożý́ wniosek - ${ }^{*}$ сложить ${ }^{*}$ заявление (заявить ходатайство).

Błędów wynikających z użycia w tłumaczeniu tzw. fałszyw ych przyjaciół tłu macza jest względnie mało. Może wynikać to $\mathrm{z}$ faktu, że studentom co do zasady zwraca się uwagę na zjawisko homonimii międzyjęzykowej już na wczesnym etapie nauki języka obcego.

Kłopotów natomiast przysparzają studentom występujące w tekstach kolokacje, często tłumaczone dosłownie - jak kalki frazeologiczne. Danuta Kierzkowska zauważa, że „istnieje powszechny konsensus co do tego, że przy tłumaczeniu w zakresie frazeologii obowiązuje konwencja docelowego języka prawnego i prawniczego" (Kierzkowska, 2002, s. 56). Pomocna w tej kwestii może być analiza tekstów paralelnych pod kątem precyzyjnego doboru odpowiednich jednostek frazeologicznych (Stec, 2018, ss. 266-273). Można przytoczyć przykłady użycia niewłaściwych ekwiwalentów kolokacji, nieistniejących w języku docelowym:

$w$ charakterze oskarżonego $-{ }^{{ }^{*}}$ в характере, ${ }^{*}$ в ипостаси ${ }^{4}$ (в качестве); zawiesić postępowanie - ${ }^{\star}$ завесить (приостановить) производство; wydać postanowienie - ${ }^{*}$ вы дать (вынести) постановление; должностное лиць - ${ }^{*}$ osoba na stanowisku (funkcjonariusz publiczny); вступить в законную силу - * wstąpić w siłe prawna (nabrać mocy prawnej, uprawomocnić się)

состав преступления - ${ }^{*}$ skład (znamiona) przestęstwa;

отменить приговор - ${ }^{*}$ odmienić (uchylić) wyrok.

4 Tutaj mamy do czynienia także z błędem stylistycznym - błędem rejestru, ponieważ unocmacb to termin religijny, oznaczający 'osobę w Trójcy Świętej’.

5 Problemy w tłumaczeniu sprawia także konstrukcja imiesłowowa вступивииц в законную силу, со znaczy 'prawomocny', czyli wg USJP „mający moc prawną, obowiązujący w świetle prawa” (Dubisz, 2005). 
Wanda Stec Interferencja w przekładzie jako skutek wzajemnych oddziaływań języków...

Spowodowane interferencją błędy składniowe, skutkujące brakiem poprawności w zakresie łączliwości leksykalnej, najczęściej wynikają z tłumaczenia syntagmatycznego, czyli „słowo po słowie”, polegającego na bezwiednym zastępowaniu struktur języka wyjściowego strukturami języka docelowego:

выцана сроком на 3 года - wydana ${ }^{\star}$ terminem na 3 lata (na okres 3 lat); представлять интересы в суде - ${ }^{*}$ przedstawiać interesy ${ }^{*} w$ sadzie (reprezentować interesy przed sqdem);

общество в лице - spółka ${ }^{\star}$ w osobie (reprezentowana przez...);

оказывать помощь, поддержку - ${ }^{\star}$ okazywać pomoc, wsparcie (nieść pomoc; udzielać pomocy, wsparcia);

причинять убытки, вред - * przyczyniać straty, szkody (przyprawiać o straty; wyrządzać szkody);

wnieść pozew - *

$w$ mоіт ітіепіи - ${ }^{*}$ в моем имени (от моего имени);

przez partnera - *через партнера (партнером);

poza obszarem UE - ${ }^{*}$ поза территорией EC (вне пределов EC);

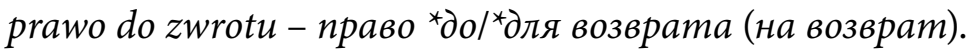

Przejawem interferencji jest także użycie w języku docelowym tłumaczenia niewłaściwego przypadka rzeczownika, prowadzące do na ruszenia zwią zku rządu. Tego typu błąd wynika $\mathrm{z}$ różnicy w rekcji między językiem polskim a rosyjskim:

występować przeciwko (komu) - выступать против ${ }^{*}$ кому (кого);

zgodność $z$ oryginałem - соответствие ${ }^{*}$ соригиналом (соответствие подлиннику; верность с подлинником);

przestrzegać zasad - соблюдать ${ }^{\star}$ правил (правила).

Często w następstwie przeniesienia do języka docelowego struktury z języka wyjściowego w tłumaczeniu pojawia się niewłaściwy szyk wyrazów (przymiotnika wobec określanego rzeczownika) w utartych połączeniach wyrazowych:

Российская Федерация - ${ }^{*}$ Rosyjska Federacja (Federacja Rosyjska);

государственные органы - * państwowe organy (organy państwowe, organy państwa);

ценные бумаги - *cenne papiery (papiery wartościowe). 
Wanda Stec Interferencja w przekładzie jako skutek wzajemnych oddziaływań języków...

W tłumaczeniach na język ojczysty wskutek interferencji tworzone są typowo rosyjskie konstrukcje $\mathrm{z}$ bezokolicznikiem, podczas gdy należałoby użyć rzeczownika odczasownikowego:

просим исполнить решение - prosimy ${ }^{*}$ wykonać orzeczenie (prosimy o wykonanie orzeczenia);

прошу предоставить кредит - proszę ${ }^{*} u d z i e l i c ́$ kredytu (proszę o udzielenie kredytu).

Wynikające z interferencji błędy na poziomie morfologii i fleksji występują głównie w tłumaczeniach na język rosyjski. Są to końcówki charakterystyczne dla paradygmatu polskiego (lub zbliżone) przy odmianie rzeczowników czy imiesłowów przymiotnikowych:

w obrocie krajowym i zagranicznуm - ${ }^{*}$ во внутренним и внешним обороте (во внутреннем и внешнем);

opóźnienia w regulowaniu zobowiązań - задержка в регулированию обязательств (регулировании);

weksle - ${ }^{*}$ вексле $($ векселя).

$\mathrm{Z}$ języka wyjściowego do języka przekładu przenoszone są zasady odmiany i tworzenia wyrazów pochodnych:

$w$ Bialymstoku ${ }^{6}{ }^{*}$ в Бялымстоке, ${ }^{*}$ Б Беломстоке (в Белостоке);

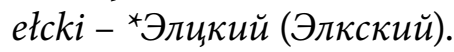

Przejawem interferencji jest użycie niewłaściwego rodzaju:

w Роzпапіи - в ${ }^{\star}$ Познане (в Познани);

podpis nieczytelny - ${ }^{\star}$ неразборчивый подпись (неразборчивая).

W przekładzie tekstów z zakresu prawa, ze względu na ich treści, przeznaczenie i performatywny charakter, poważne uchybienie stanowią obciążone interferencją błędy w zakresie terminologii. Są one następstwem nieznajomości odpowiedników terminologicznych w języku docelowym tłumaczenia, przez co wyrazy języka ogólnego używane są w znaczeniu terminów:

решение суда - ${ }^{*}$ decyzja (orzeczenie) sąu;

${ }^{6}$ Odmieniają się obydwa człony, w tym Biały odmienia się jak przymiotnik. 
Wanda Stec Interferencja w przekładzie jako skutek wzajemnych oddziaływań języków...

явиться - ${ }^{*}$ zjawić się (stawić się);

виновный, виновник - ${ }^{*}$ winny, ${ }^{*}$ winien, ${ }^{*}$ winowajca $(\text { sprawca })^{7}$.

W tłumaczeniach widoczne jest również nierozróżnianie znaczeń terminów i kolokacji prawniczych - zarówno w języku oryginału, jak i przekładu: rosyjskim odpowiednikiem wezwania może być вызов albo повестка, nр. повестка о вызове в суд, на допрос ${ }^{8}$. Mylnie stosowane są kolokacje związane z karaniem: podlegać bądź nie podlegać karze może sprawca (виновный подлежит наказанию), natomiast czyn nie podlega karze, ale zagrożony jest kara, np. grzywny (деяние наказывается штрабом). Postępowanie w procedurach prawa karnego procesowego bywa nieprawidłowo tłumaczone jako ${ }^{*}$ поведение, podczas gdy odpowiedniki w składzie terminów dwuczłonowych mogą być różne: postępowanie karne to уголовное судопроизводство, zaś postępowanie ргzуgотожажсzе - предварительное расследование.

W pewnym stopniu interferencja ma związek z błęda mi wynikającymi z nieznajomości realiów w zakresie prawa. W tłumaczeniu automatycznie przenoszone są realia kraju języka wyjściowego na odmienny system prawny kraju języka docelowego. Nieuwzględnianie tej specyfiki, przekładającej się na różnice terminologiczne, staje się przyczyną wyboru niewłaściwego ekwiwalentu. Rosyjskim odpowiednikiem przekładowym pojęcia oskarżony, w zależności od etapu postępowania karnego, może być обвиняемый bądź подсудимый. Akt oskarżenia to обвинительный акт ${ }^{9}$ albo обвинительное заключение. Показания najczęściej tłumaczone są jako zeznania, podczas gdy w polskim procesie karnym zeznania składają świadek i pokrzywdzony, natomiast podejrzany i oskarżony składają wyjaśnienia. Zatem kolokacja daвams показания mоże zostać przetłumaczona jako składać zeznania albo składać wyjaśnienia, w zależności od tego, kogo dotyczy dana czynność procesowa.

Interferencja w procesie przekładu pociąga za sobą także błędy stylistyczne, polegające na naruszeniu norm poprawności stylistycznej i uzusu użytkowników języka docelowego. W tłumaczeniach studentów występuje słownictwo zaczerpnięte $\mathrm{z}$ innego stylu:

7 Tu interferencja występuje również w tłumaczeniu na język rosyjski, przy czym w tym wypadku form błędnych bywa więcej: ${ }^{\star}$ винньй ${ }^{\star}$ виноватыц

${ }^{8}$ W wypadku, gdy jest to pismo urzędowe, np. wezwanie do sądu, na przesłuchanie itp.

9 Jeśli postępowanie przygotowawcze prowadzone jest $\mathrm{w}$ trybie dochodzenia. 
Wanda Stec Interferencja w przekładzie jako skutek wzajemnych oddziaływań języków...

\section{ukarany - *uтрафник (наказанньй);}

дознаватель - *dochodzeniowiec (prowadzacy dochodzenie, oficer dochodzeniowy);

skazany zamieszkuје - осужденный ${ }^{\star}$ жиет (проживает);

stosowane są nieuzasadnione skrótowce mające zabarwienie stylistyczne:

sąd rejonowy - * райсуд (районный суд).

Niekiedy ma miejsce mylenie wyrazów i przypisywanie im błędnych znaczeń, jak w przypadku par: czyn a czynnośćldziałanie (деяние a действие). Wskutek interferencji niewłaściwie tłumaczone są zwroty adresatywne ${ }^{10}: 2-\varkappa e$ Зайцевой A. - ${ }^{\star}$ Pani Zajcewoj A., ${ }^{\star}$ Do Pani Zajcewej A. (Pani A. Zajcewa lub: Do Pani A. Zajcewej).

Błędy ortograficzne wywołane interferencją polegają na przenoszeniu podczas tłumaczenia zasad języka wyjściowego dotyczących pisowni nazewnictwa wielką i małą literą, np. toponimów, nazw uczelni, instytucji i in.

Identyfikacja i analiza błędów w tłumaczeniu może być pomocna w nauczaniu i w praktyce przekładu specjalistycznego, służąc wyrobieniu oraz doskonaleniu umiejętności translatorskich. Jeśli indywidualne przypadki występowania interferencji nie zostaną w porę uświadomione młodym adeptom przekładu prawniczego, może to doprowadzić do powtarzania, a w konsekwencji - utrwalenia błędnych struktur oraz elementów językowych. Bardzo ważne jest przy tym, jak słusznie zauważa Dzierżanowska (Dzierżanowska, 1990, s. 43), zwalczanie tendencji do przekładu dosłownego. Przydatne mogą być wstępne ćwiczenia gramatyczno-tłumaczeniowe, w szczególności intensywna i regularna praca nad słownictwem oraz frazeologią (kolokacjami), których nieznajomość stanowi przyczynę najczęściej występujących błędów wynikających z transferu negatywnego. Bardzo istotne jest staranne omawianie wykonywanych tłumaczeń pod kątem błędów interferencyjnych różnego typu, zarówno zaistniałych, jak i potencjalnych (prognozowanie błędów w tłumaczeniu). Ważne jest zwrócenie uwagi na sedno problemu, a wszelka krytyka winna mieć charakter konstruktywny (zwłaszcza w przypadku błędów nieakceptowalnych) oraz

${ }_{10}$ Niewłaściwa kolejność podania imienia lub jego inicjału i nazwiska, niewłaściwy przypadek. 
Wanda Stec Interferencja w przekładzie jako skutek wzajemnych oddziaływań języków...

być ukierunkowana na zmotywowanie do dalszej nauki i rozwoju kompetencji. Warto też poświęcić czas na wyszukiwanie i analizę tekstów paralelnych w dwóch językach. Umożliwi to studentom tłumaczenie bez efektu „obcości w odbiorze przekładu” (Lewicki, 2000) ${ }^{11}$, szczególnie jednostek tekstu niosących konotację obcości, unikanie tworzenia form nieuzualnych, a jednocześnie ułatwi zrozumienie zarówno samych tekstów, jak i realiów prawnych kraju języka, z którego i na który tłumaczą.

Podsumowując refleksje na temat interferencji w przekładzie, warto przytoczyć słynną dychotomiczną zasadę tłumaczenia, będącą maksymą zawodową tłumaczy: „Non verbum e verbo, sed sensum exprimere de sensu”" Twórcą tych słów jest patron tłumaczy - Hieronim ze Strydonu (340-420), czyli św. Hieronim, autor Wulgaty, który w Liście do Pammachiusza w ten właśnie sposób wypowiedział się przeciwko dosłowności w tłumaczeniu (Sochacki, 2013, ss. 121-138).

\section{Bibliografia}

Alimov, V. V. (2006). Teoriia perevoda: Perevod w sfere professional'noi kommunikatsii. KomKniga.

Bawej, I. (2008). Błąd leksykalny jako skutek procesów interferencyjnych: Poradnik metodyczny dla dydaktyków języka niemieckiego. Wydawnictwo Uniwersytetu Kazimierza Wielkiego.

Bugajski, M. (2006). Język w komunikowaniu. Wydawnictwo Naukowe PWN.

Choduń, A. (2007). Stownictwo tekstów aktów prawnych w zasobie leksykalnym wspótczesnej polszczyzny. Wydawnictwo Trio.

Cieszyńska, J. (2006). Dwujęyczność, dwukulturowość - przekleństwo czy bogactwo?: O poszukiwaniu tożsamości Polaków w Austrii. Wydawnictwo Naukowe Akademii Pedagogicznej im. Komisji Edukacji Narodowej.

Dąmbska-Prokop, U. (Red.). (2000). Mała encyklopedia przekładoznawstwa (J. Brzozowski, Oprac.). Wydawnictwo Wyższej Szkoły Ekonomii i Języków Obcych EDUCATOR.

Dubisz, S. (Red.). (2005). Uniwersalny stownik jezzka polskiego [CD-ROM wersja 1.0]. Wydawnictwo Naukowe PWN SA.

11 Zdaniem Romana Lewickiego obcość w odbiorze przekładu „wywołana na poziomie błędu występuje głównie w przekładach na język obcy", ponieważ w tego typu przekładach najczęściej spotyka się błędy językowe, w odróżnieniu od przekładów na język ojczysty, w których przeważają błędy przekładowe (Lewicki, 2000, s. 142).

12 „Nie słowo za słowem, lecz myśl za myślą” lub „Nie słowo w słowo, lecz by myśl odpowiadała myśli". 
Wanda Stec Interferencja w przekładzie jako skutek wzajemnych oddziaływań języków...

Dzierżanowska, H. (1990). Przekład tekstów nieliterackich: Na przykładzie języka angielskiego. Państwowe Wydawnictwo Naukowe.

Gasek, B. (2012). Leksiko-semanticheskaia interferentsiia v protsesse perevoda (na materiale russkogo i pol'skogo iazykov). Wydawnictwo Uniwersytetu Wrocławskiego.

Grucza, F. (Red.). (1978). Z problematyki błędów obcojęzycznych. Wydawnictwa Szkolne i Pedagogiczne.

Grucza, F. (1981). Zagadnienia translatoryki. W F. Grucza (Red.), Glottodydaktyka a translatoryka (ss. 9-30). Wydawnictwa Uniwersytetu Warszawskiego.

Guławska-Gawkowska, M. (2005). Stylistyka i kultura języka polskiego dla tłumaczy. NEOFILOLOG, 26, 70-77.

Kierzkowska, D. (2002). Tłumaczenie prawnicze. Wydawnictwo TEPIS.

Kozłowska, Z. (2002). O błędach językowych w tekstach polskich przekładów. W A. Kopczyński \& U. Zaliwska-Okrutna (Red.), Język rodzimy a język obcy: Komunikacja, przekład, dydaktyka (ss. 137-149). Wydawnictwa Uniwersytetu Warszawskiego.

Kozłowska, Z., \& Szczęsny, A. (2018). Tłumaczenie pisemne na język polski: Kompendium. Wydawnictwo Naukowe PWN.

Kubacki, A. (2014). Tłumacz przysięgły w polskim systemie wymiaru sprawiedliwości. Kwartalnik Krajowej Szkoły Sądownictwa i Prokuratury, 4(15), 46-64.

Lewicki, R. (2000). Obcość w odbiorze przekładu. Wydawnictwo Uniwersytetu Marii Curie-Skłodowskiej.

Lukszyn, J. (Red.). (1998). Tezaurus terminologii translatorycznej. Wydawnictwo Naukowe PWN.

Markowski, A. (2005). Kultura jezzyka polskiego: Teoria: Zagadnienia leksykalne. Wydawnictwo Naukowe PWN.

Nawacki, M., \& Nawacka, J. (2007). Z obserwacji nad kontekstowym rozumieniem tekstu prawnego jako podstawą translacji. Acta Polono-Ruthenica, 12, 145-159.

Płużyczka, M. (2015). Tłumaczenie a vista: Rozważania teoretyczne i badania eyetrackingowe. Wydawnictwo Naukowe Instytutu Komunikacji Specjalistycznej i Interkulturowej UW.

Sękowska, E. (2010). Język emigracji polskiej w świecie: Bilans i perspektywy badawcze. Wydawnictwo Uniwersytetu Jagiellońskiego.

Sochacki, D., OCD. (2013). Hieronim ze Strydonu na progu europejskich strategii tłumaczeniowych. Źródła Humanistyki Europejskiej, 6, 121-138.

Stec, W. (2018). Kolokacje prawne jako źródło problemów tłumaczeniowych (na przykładzie polskich i rosyjskich tekstów paralelnych z zakresu prawa karnego procesowego). W A. Pstyga, T. Kananowicz, \& M. Buchowska (Red.), Słowo z perspektywy językoznawcy i tłumacza 7 (ss. 266-274). Wydawnictwo Uniwersytetu Gdańskiego.

Szulc, A. (1984). Podręczny słownik językoznawstwa stosowanego. Państwowe Wydawnictwo Naukowe.

Toury, G. (1995). Descriptive translation studies and beyond. J. Benjamins Publishing. https:// doi.org/10.1075/btl.4 
Walczak, B. (2014). Trzy refleksje o dwujęzyczności. Poznańskie Spotkania Językoznawcze, 27, 181-191. https://doi.org/10.14746/psj.2014.XXVII.15

\title{
Interference Between Languages in Translation (Observations Based on Polish- Russian Translations of Legal Texts)
}

\author{
Summary
}

This article considers the issue of language transfer in translation. External interference is one of the most common reasons behind the lack of equivalence between the source text and the target text. Negative transfer leads to the lack of linguistic correctness as well as to modifying or altering the meaning of the translated text. In the didactics of translation, the rationale behind identifying and analysing linguistic errors is to develop and improve translation skills. The issue in focus is presented based on translations of legal texts in the Polish-Russian language pair.

\section{Interferencja w przekładzie jako skutek wzajemnych oddziaływań języków (na przykładzie tłumaczeń tekstów z zakresu prawa w parze językowej polski-rosyjski)}

Streszczenie

W tekście przedstawiono zagadnienia transferu językowego w przekładzie. Interferencja zewnętrzna uważana jest za jedną z podstawowych przyczyn zakłócenia ekwiwalencji między tekstem źródłowym a docelowym tłumaczenia. Transfer negatywny przyczynia się do braku poprawności językowej, modyfikacji czy zmiany sensu w przetłumaczonym tekście. W dydaktyce przekładu 
Wanda Stec Interferencja w przekładzie jako skutek wzajemnych oddziaływań języków...

identyfikacja i analiza błędów służą wyrobieniu i doskonaleniu umiejętności translatorskich. Temat zaprezentowano na materiale tłumaczeń prawniczych w parze językowej polski-rosyjski.

Keywords: language interference; legal translation; translation error; interlinguistic contacts

Słowa kluczowe: interferencja; tłumaczenie prawnicze; błąd w przekładzie; kontakty międzyjęzykowe

Wanda Stec, University of Gdansk, Gdańsk, Poland

ORCID: https://orcid.org/0000-0003-2530-2489

Correspondence: wanda.stec@ug.edu.pl

The preparation of this article was financed by the author and within the statutory activity of the Institute of Russian and Eastern Studies, University of Gdansk.

Competing interests: The author declares that she has no competing interests. 